\title{
Substrates, Wounding, and Growth Regulator Concentrations Alter Adventitious Rooting of Baldcypress Cuttings
}

\author{
Andrew R. King ${ }^{1,5}$ and Michael A. Arnold ${ }^{2}$ \\ Department of Horticultural Sciences, Texas A\&M University, HFSB 201, \\ College Station, TX 77843-2133
}

\author{
Douglas F. Welsh ${ }^{3}$ \\ Texas AgriLife Extension Service, Department of Horticultural Sciences, \\ College Station, TX 77843-2134
}

\author{
W. Todd Watson ${ }^{4}$ \\ Department of Ecosystem Science and Management, Texas A\&M University, \\ College Station, TX 77843-2138
}

Additional index words. Taxodium distichum, rooted cuttings, adventitious rooting, IBA (indole-3-butyric acid), vegetative propagation

\begin{abstract}
In previous studies, baldcypress [Taxodium distichum (L.) Rich.] clones were selected for tolerance to high $\mathrm{pH}$ soils, drought and salt exposures, and ornamental characteristics. The objective of the current research was to determine the treatment combinations that yielded optimum root quantity (percentage) and rooted cutting quality (root number, length, dry mass, and shoot dry mass) on vegetative cuttings for a representative clone. Cuttings were treated with factorial combinations of one of four potassium salt of indole-3-butyric acid (K-IBA) concentrations $[0,5,000,10,000,15,000$ $\mathrm{mg} \cdot \mathrm{L}^{-1}(0,20.72,41.44,62.16 \mathrm{~mm}$, respectively)], wounded or not wounded (1-cm long basal incision), and rooted in one of three substrates $(100 \%$ perlite, $100 \%$ peatmoss, or $50 \%$ perlite:50\% peatmoss). Data indicated a tradeoff between potential rooting quantity and root quality measurements in response to different substrates. Although rooting percentages were affected by substrates only at $P \leq 0.10(53 \%$ in $100 \%$ perlite versus $36 \%$ in $100 \%$ peatmoss), there were highly significant $(P \leq 0.0001)$ differences in rooted cutting potential among substrates as measured by the percentage of cuttings with basal callus. Cuttings placed in $100 \%$ perlite callused at $85 \%$, whereas cuttings placed in $100 \%$ peatmoss callused at $\approx 53 \%$. The $100 \%$ peatmoss treatment, however, yielded cuttings with significantly greater root quality for all measurements, except root number per cutting. Wounding cuttings proved to have deleterious effects on root quality measurements. Total root length was $\approx 14.5 \mathrm{~cm}$ for non-wounded cuttings and $\approx 10.8 \mathrm{~cm}$ for wounded cuttings. Increasing K-IBA concentrations did not significantly $(P \leq 0.05)$ affect rooting or callus percentages but did significantly affect root dry mass, total root length, and average root length per cutting. Total root length increased from $10.8 \mathrm{~cm}$ at $0 \mathrm{mg} \cdot \mathrm{L}^{-1} \mathrm{~K}$-IBA to $16 \mathrm{~cm}$ at $15,000 \mathrm{mg} \cdot \mathrm{L}^{-1} \mathrm{~K}$-IBA. Mean root number per cutting increased from $\approx 1.6$ with wounded cuttings planted in $100 \%$ peatmoss to $\approx 3.1$ with non-wounded cuttings planted in $100 \%$ perlite. Results suggested that high-quality softwood baldcypress cuttings should not be wounded, should be treated with $15,000 \mathrm{mg} \cdot \mathrm{L}^{-1} \mathrm{~K}-\mathrm{IBA}$, and grown in a substrate with intermediate water-holding capacity to achieve an acceptable balance between rooting percentage and rooted cutting quality objectives.
\end{abstract}

Baldcypress, Taxodium distichum (L.) Rich., is a highly adaptable tree of significant ecological importance in the southeastern United States (Arnold, 2008; Pezeshki and DeLaune, 1994). Baldcypress is typically propagated commercially from seed, grafting, or produced through cuttings (Dirr, 2009; Thomsen, 1978). Baldcypress seeds exhibit a dormancy that is easily overcome with stratification (Dirr, 2009); however, seedling material lacks uniformity (Pezeshki and DeLaune, 1994). Grafting baldcypress is a reliable method of propagation (Dirr, 2009) but is the most expensive of the three methods (Thomsen, 1978). Vegetative propagation by cuttings yields uniform plants and through selection can be used to expedite narrow sense heritable genetic improvement in this species (Pezeshki and DeLaune, 1994). Relatively high percentages of successful rooting have been reported for Taxodium supporting the practice of commercially propagating baldcypress by cuttings. Rooting percentages and rooted cutting quality do, however, vary among genotypes (Copes and Randall, 1993; King, 2010; Pezeshki and DeLaune, 1994; St. Hilaire, 2003; Zhou, 2005).

There are many methods for manipulating cuttings to encourage optimal adventitious root formation. Most of these methods fall under three main categories: management of the ortet (or stock plant), treatment of cuttings during propagation, or management of the environment surrounding the cuttings during propagation (Hartmann et al., 2011). The majority of the research conducted on asexual propagation of baldcypress by cuttings has focused on the treatment of cuttings during propagation. Testing different types and concentrations of synthetic auxin (King, 2010; Pezeshki and DeLaune, 1994; St. Hilaire, 2003; Zhou, 2005) or wounding the basal portion of the cutting (Zhou, 2005) are the most common of these treatments. Management of the ortet has also been tested by making the timing of cutting harvest the independent variable in an experiment (King, 2010; Zhou, 2005). It has not been common, however, to manipulate the environment surrounding the cuttings during propagation. In most instances, the environment has been constant across all treatment combinations (Copes and Randall, 1993; King, 2010; Pezeshki and DeLaune, 1994; St. Hilaire, 2003; Zhou, 2005). Lu et al. (2004) conducted the only study to our knowledge investigating the effects of manipulating the surroundings of baldcypress cuttings by planting them in three different rooting substrates.

Rooting substrates are typically comprised of an organic component (i.e., peatmoss) and an inorganic component (i.e., perlite), which increases aeration. A rooting substrate serves a number of purposes, including anchoring the cutting in place, holding water for the cutting, supplying sufficient aeration for adventitious rooting, and reducing the amount of irradiance that reaches the base of the cutting (Hartmann et al., 2011). The uptake of water in cuttings is proportional to the content of water, by volume, in the rooting substrate (Grange and Loach, 1983; Rein et al., 1991). Water in excess, however, prevents proper aeration (Erstad and Gislerod, 1994). Copes and Randall (1993) found that baldcypress rooted at greater percentages when positioned in the wettest portion of the mist bench tested ( $50 \%$ water content, by weight) as opposed to two more aerated portions ( $40 \%$ and $29 \%$ water content by weight, respectively). Cuttings rooted at $58 \%, 33 \%$, and $6 \%$ when stuck in the mist bench with $50 \%, 40 \%$, and $29 \%$ water content, respectively. Little else is known about the specific substrate requirements for rooting baldcypress cuttings. The lack of available research on vegetative propagation of baldcypress by cuttings necessitates a look at the literature dealing with vegetative propagation of other coniferous species by cuttings. Kolasinski (2006) rooted softwood dawn redwood, Metasequoia glyptostroboides (Hu and W.C. Cheng) cuttings, a closely related species to baldcypress, in a 1:1 (v:v) mix of peat and perlite, respectively. Rooting for the 3-year study averaged 93\%. Mazăre et al. (2007) conducted rooting experiments on Picea glauca (Moench.) Voss. 'Conica'. Treatments included six different substrates (100\% sand, $100 \%$ peatmoss, $100 \%$ perlite, $1: 1$ sand with peat, $1: 1$ sand with perlite, $1: 1$ 
peat with perlite). Rooting percentages were greatest in the sand with peat substrate, whereas root quality (determined visually by the number of primary and secondary roots) was greatest in the perlite with peat. Although research on other closely related species is helpful, it is difficult to determine the environmental factors that will lead to optimum rooting percentage and root quality for Taxodium cuttings based on that research (Ragonezi et al., 2010).

All cuttings are by definition wounded. Increasing the area of mechanical wounding however has been shown to enhance wound responses in some species, including increasing the division of the cambial cells, which may lead to adventitious root formation (Mackenzie et al., 1986). Zhou (2005) included a wounding treatment in a number of experiments conducted on a baldcypress clone [T302, T. distichum var. distichum $\times T$. distichum var. mexicanum (Carrière) Gordon]. Cuttings were incision-wounded (1-cm basal cut along the vertical axis) or not. One experiment included a wounding treatment that did not significantly affect $(P \leq 0.05)$ rooting percentage or root density ranking (RDR) (a qualitative method of ranking root system quality) (Zhou, 2005). Another experiment however included a wounding treatment that did significantly affect $(P \leq 0.05)$ both rooting percentage and RDR. Wounded treatments in Zhou (2005) produced cuttings with a 1.6 and 1.8 times greater rooting percentage and RDR, respectively, than did non-wounded treatments. Kolasinski (2006) included similar incision wounding treatments in a propagation study of dawn redwood. No significant difference $(P \leq$ 0.05 ) was found among the wounded and nonwounded treatments for rooting percentage, mean root number per cutting, or mean total root length. Wounding increased mean root length per cutting. Wounded cuttings averaged $9.0 \mathrm{~cm}$, whereas non-wounded cuttings averaged $8.4 \mathrm{~cm}$. De Silva et al. (2005) included three wounding treatments (none, single wound, and double wound) on pre-callused cuttings of leyland cypress, $\times$ Cupressocyparis leylandii (A.B. Jacks. and Dallim.) Dallim. The single wound treatment was applied by detaching callus tissue on one side of the cutting, whereas the double wound treatment was

Received for publication 28 Apr. 2011. Accepted for publication 28 July 2011 .

This work was supported in part by funds from Texas AgriLife Research.

Mention of a trademark, proprietary product, or vendor does not constitute a guarantee or warranty of the product by the authors, Texas A\&M University, or Texas AgriLife Research and does not imply its approval to the exclusion of other products or vendors that also may be suitable.

This study was included as part of a thesis written in partial fulfillment of the requirements for the M.S. degree by A.R. King.

${ }^{1}$ Research Associate and Graduate Student.

${ }^{2}$ Professor.

${ }^{3}$ Professor and Associate Department Head.

${ }^{4}$ Adjunct Professor.

${ }^{5}$ To whom reprint requests should be addressed; e-mail aking@tamu.edu. applied by detaching the callus on opposite sides. Rooting percentage and the percentage of cuttings with acceptable root symmetry (a visual rating) were significantly $(P \leq 0.05)$ affected by an interaction among wounding and indole-3-butyric acid (IBA).

Treating cuttings with differing auxin concentrations or a.i. has been one of the most common treatments in research on baldcypress propagation by cuttings (King, 2010; Pezeshki and DeLaune, 1994; St. Hilaire, 2003; Zhou, 2005). Pezeshki and DeLaune (1994) found that when baldcypress cuttings were taken from 1-year-old trees and treated or untreated with a $1000 \mathrm{mg} \cdot \mathrm{kg}^{-1}$ powder concentration of IBA (ROOTONE®; Ferti-lome Co., Bonham, TX), they rooted at similar percentages $(88 \%$ and $75 \%$ for the 0 IBA and $1000 \mathrm{mg} \cdot \mathrm{L}^{-1}$ IBA treatments, respectively). These cuttings did however show significantly greater $(P \leq 0.05)$ shoot dry weights when treated with IBA. Mean shoot dry weights were $10.90 \mathrm{~g}$ and $2.86 \mathrm{~g}$ for treated and untreated cuttings, respectively. St. Hilaire (2003) observed an increase in rooting percentage of $T$. distichum var. mexicanum softwood cuttings after treatment with increasing concentrations of IBA. In 1 year of the study, rooting percentages were $48 \%$ and $82 \%$ for 3000 and $8000 \mathrm{mg} \cdot \mathrm{L}^{-1}$ IBA, respectively. Zhou (2005) found that rooting percentages increased with increasing levels of K-IBA. Cuttings treated with 5,000 and $10,000 \mathrm{mg} \cdot \mathrm{L}^{-1}$ K-IBA rooted at $57.6 \%$ and $68.1 \%$, respectively. Cuttings treated with 0 and $2500 \mathrm{mg} \cdot \mathrm{L}^{-1}$ K-IBA rooted at the significantly lower $(P \leq$ 0.05 ) rates of $16.6 \%$ and $22.2 \%$, respectively. Kolasinski (2006) studied the effect of the growth regulator Seradix B No. 1 (2000 $\mathrm{mg} \cdot \mathrm{kg}^{-1}$ IBA) on softwood dawn redwood cuttings. Rooting percentage, mean root number per cutting, and mean total root length were all significantly $(P \leq 0.05)$ greater when treated with the growth regulator. Rooting percentage increased from $91 \%$ in the control to $95 \%$ with the application of IBA. De Silva et al. (2005) also included a growth regulator treatment of $0,5,000$ and $10,000 \mathrm{mg} \cdot \mathrm{L}^{-1}$ IBA when rooting pre-callused leyland cypress cuttings. A significant $(P \leq 0.05)$ interaction was found among IBA concentrations and wounding treatments. The greatest rooting percentage of $63.9 \%$ was found in the 10,000 $\mathrm{mg} \cdot \mathrm{L}^{-1}$ IBA, double-wounded treatment. The percentage of cuttings with acceptable root symmetry was also highest for this treatment.

The objective of the current research was to determine combinations of rooting substrate, wounding treatment, and K-IBA concentration that yielded optimal percentages of rooted cuttings and root systems of optimal quality with baldcypress cuttings.

\section{Materials and Methods}

Softwood baldcypress cuttings were taken on 3 June 2009 from a 4-year-old clone grown in a research plot in College Station, TX (lat. $30^{\circ} 37^{\prime} 645^{\prime \prime} \mathrm{N}$; long. 96²2'319" W). Mean length of cuttings was $12.5 \mathrm{~cm}$. Cuttings were kept overnight in a cooler at 8 to $9{ }^{\circ} \mathrm{C}$ in plastic bags partially filled with water to ensure hydration and planted the next day. Before planting, cuttings were randomly assigned a factorial combination of a K-IBA concentration, a wounding treatment, and a rooting substrate. Four concentrations of K-IBA (SigmaAldrich Chemical, St. Louis, MO) were tested: no growth regulator (control); 5,000 $\mathrm{mg} \cdot \mathrm{L}^{-1} \mathrm{~K}$ IBA (20.72 mM); 10,000 mg. L ${ }^{-1} \mathrm{~K}-\mathrm{IBA}$ (41.44 $\mathrm{mM})$; or $15,000 \mathrm{mg} \cdot \mathrm{L}^{-1} \mathrm{~K}-\mathrm{IBA}(62.16 \mathrm{~mm})$. Growth regulator treatments were administered by dissolving the K-IBA in water and submerging the basal $5 \mathrm{~cm}$ of the cutting into the randomly assigned solution for $5 \mathrm{~s}$. Half of the cuttings from each K-IBA treatment were wounded by making a $1-\mathrm{cm}$ incision along the axis into the basal end of the cutting; the other half was not wounded (control). Wounding treatments were administered before application of growth regulator. Three substrates were tested: $100 \%$ perlite (Sunshine ${ }^{\circledR}$ Strong Lite coarse grade perlite; Sun Gro ${ }^{\circledR}$ Horticulture, Seba Beach, AB, Canada); $100 \%$ peatmoss (Sunshine ${ }^{\circledR}$ Peat Moss; Sun Gro ${ }^{\circledR}$ Horticulture); and a mix 1:1 (by volume) perlite:peatmoss. Bulk density, macropore space, micropore space (water-holding capacity), $\mathrm{pH}$, electrical conductivity (EC), and particle size distribution measurements were taken for each substrate. Sieve sizes used for particle size distribution were $3.35 \mathrm{~mm}, 1.68 \mathrm{~mm}, 0.422 \mathrm{~mm}, 0.251$ $\mathrm{mm}, 0.125 \mathrm{~mm}$, and $0.066 \mathrm{~mm}$. Cuttings were planted $5 \mathrm{~cm}$ deep into the randomly assigned rooting substrate in black plastic flats, $10 \mathrm{~cm} \times$ $36 \mathrm{~cm} \times 51 \mathrm{~cm}$ (Dyna-flat ${ }^{\mathrm{TM}}$; Kadon Corp., Dayton, $\mathrm{OH}$ ). Each factorial combination of K-IBA, substrate, and wounding treatment was tested on 30 cuttings, 10 in each of three blocks, which yielded 720 total cuttings. Cuttings were planted in a modified randomized completed block design consisting of four K-IBA concentrations, three substrates, and two wounding treatments. Flats were placed on benches in a polyethylene greenhouse at Texas A\&M University Horticultural Gardens (College Station, TX). Cuttings were misted intermittently with reverse osmosis-treated water for a period of $10 \mathrm{~s}$ on a 16-min cycle during daylight hours. Nozzles were located $46 \mathrm{~cm}$ above the rooting substrate. Substrate temperatures were measured with the Omega ${ }^{\circledR}$ HH309 data logger thermometer (Omega Engineering, Inc., Stamford, CT). Photosynthetically active radiation $(P A R)$ encountered by the cuttings was measured with a ceptometer (Accupar; Decagon Devices, Inc., Pullman, WA) at the canopy level periodically throughout the experiment. Cuttings were allowed to root for 8 weeks and were destructively harvested on 5 to 10 Aug. 2009. Information gathered from all cuttings included determination of the production of callus tissue, the presence of root formation, and the number of roots produced per cutting. From each replicate treatment combination, five rooted cuttings were randomly selected from which root length and root and shoot dry mass were measured. In replicate treatment combinations that did not yield five rooted cuttings, those that did root were preferentially selected along with randomly selected unrooted cuttings until 
five samples were obtained. Possible interactions among K-IBA concentration, wounding treatment, and rooting substrate were analyzed using the general linear models procedure in SAS and means were compared using least squared means procedures (SAS 9.1 for Windows; SAS Institute, Cary, NC). An arcsine transformation was applied to the rooting and callus percentage data to ensure a more normal distribution. The highest order significant $(P \leq 0.05)$ interaction(s) for a given parameter is presented. When higher-order interactions were non-significant, data were pooled and significant lower-order interactions or main effects are presented. When the interval K-IBA concentrations were significant, polynomial regression equations for those effects were fitted to the data and are presented where significant $(P \leq 0.05)$.

\section{Results and Discussion}

Mean $P A R$ at the canopy level in the mist bench was $461.1 \mu \mathrm{mol} \cdot \mathrm{m}^{-2} \cdot \mathrm{s}^{-1}$. Mean ambient temperature and temperature in the rooting substrate was 27.5 and $29.5{ }^{\circ} \mathrm{C}$, respectively. All measured substrate characteristics were significantly different $(P \leq 0.05)$ among the three substrates with the exception of the particle size distribution in the smallest sieve used $(0.066 \mathrm{~mm})$ (Tables 1 and 2). The 100\% peatmoss and $100 \%$ perlite substrates were significantly $(P \leq 0.05)$ different for most characteristics measured. The 1:1 mixed substrate was typically intermediate between the peatmoss and perlite. The mixed substrate was not significantly $(P \leq 0.05)$ different from the peatmoss in bulk density, $\mathrm{pH}$, and EC and was not significantly $(P \leq 0.05)$ different from the perlite in macropore space suggesting that both the peatmoss and the perlite provided distinct characteristics to the 1:1 mix (Table 1). Further reinforcing this point were significant $(P \leq 0.05)$ differences in micropore space (water-holding capacity) for all three substrates with the mixed substrate exhibiting an intermediate water-holding capacity (Table 1). Peat moss had a larger proportion of particulate matter between $1.68 \mathrm{~mm}$ and $0.25 \mathrm{~mm}$ and above $3.35 \mathrm{~mm}$ than perlite substrates (Table 2). The mixed substrate was similar to perlite in particulate composition above $1.68 \mathrm{~mm}$ in diameter but was similar to the peatmoss substrate composition for particles less than $1.68 \mathrm{~mm}$ in diameter (Table 2).

All root and shoot parameters measured were significantly affected $(P \leq 0.05)$ by at least one of the treatments tested with the exception of rooting percentage (Table 3 ). Two-way interactions were found for root dry mass and average root length and three-way interactions occurred for shoot dry mass and root number per cutting. Main effects were found for all other parameters measured except rooting percentage.

Table 1. Characteristics of three rooting substrates (100\% peatmoss, $100 \%$ perlite, $1: 1$ peatmoss:perlite) used in the asexual propagation of $T$. distichum through cuttings.

\begin{tabular}{lccccr}
\hline Substrate & $\begin{array}{c}\text { Bulk density } \\
\left(\mathrm{mg} \cdot \mathrm{cm}^{3}\right)\end{array}$ & $\begin{array}{c}\text { Macropore } \\
\text { space }(\%)\end{array}$ & $\begin{array}{c}\text { Micropore } \\
\text { space }(\%)\end{array}$ & $\mathrm{pH}$ & $\begin{array}{c}\mathrm{EC} \\
\left(\mu \mathrm{S} \cdot \mathrm{cm}^{-1}\right)\end{array}$ \\
\hline $100 \%$ peatmoss & $104.0 \mathrm{a}^{\mathrm{z}}$ & $0.168 \mathrm{~b}$ & $0.567 \mathrm{a}$ & $4.87 \mathrm{~b}$ & $168.3 \mathrm{a}$ \\
$1: 1 \mathrm{mix}$ & $95.5 \mathrm{a}$ & $0.388 \mathrm{a}$ & $0.475 \mathrm{~b}$ & $4.90 \mathrm{~b}$ & $152.3 \mathrm{a}$ \\
$100 \%$ perlite & $70.4 \mathrm{~b}$ & $0.471 \mathrm{a}$ & $0.290 \mathrm{c}$ & $7.60 \mathrm{a}$ & $78.7 \mathrm{~b}$ \\
\hline
\end{tabular}

${ }^{\mathrm{z}}$ Means within columns followed by the same letter are not different using least squared means comparisons at $P \leq 0.05$. Values represent means of three observations.

$\mathrm{EC}=$ electrical conductivity.

Table 2. Particle size distribution of three rooting substrates $(100 \%$ peatmoss, $100 \%$ perlite, $1: 1$ peatmoss:perlite) used in the asexual propagation of $T$. distichum through cuttings.

\begin{tabular}{lcccccc}
\hline & Sieve 1 & Sieve 2 & Sieve 3 & Sieve 4 & Sieve 5 & Sieve 6 \\
Substrate & $(3.35 \mathrm{~mm})(\mathrm{g})$ & $(1.68 \mathrm{~mm})(\mathrm{g})$ & $(0.42 \mathrm{~mm})(\mathrm{g})$ & $(0.25 \mathrm{~mm})(\mathrm{g})$ & $(0.13 \mathrm{~mm})(\mathrm{g})$ & $(0.07 \mathrm{~mm})(\mathrm{g})$ \\
\hline $100 \%$ & $41.77 \mathrm{a}^{\mathrm{z}}$ & $11.27 \mathrm{c}$ & $38.13 \mathrm{a}$ & $7.93 \mathrm{ab}$ & $0.82 \mathrm{~b}$ & $0.04 \mathrm{a}$ \\
$\quad$ peatmoss & & & & & & \\
$1: 1 \mathrm{mix}$ & $24.87 \mathrm{~b}$ & $23.73 \mathrm{~b}$ & $38.20 \mathrm{a}$ & $10.13 \mathrm{a}$ & $2.83 \mathrm{a}$ & $0.16 \mathrm{a}$ \\
$100 \%$ perlite & $26.43 \mathrm{~b}$ & $41.00 \mathrm{a}$ & $25.00 \mathrm{~b}$ & $5.83 \mathrm{~b}$ & $1.71 \mathrm{ab}$ & $0.06 \mathrm{a}$
\end{tabular}

${ }^{\mathrm{z}}$ Means within columns, followed by the same letter are not different using least squared means comparisons at $P \leq 0.05$. Values represent means of three observations.

Table 3. Levels of significance of analysis of variance effects for select rooting parameters and shoot dry mass.

\begin{tabular}{|c|c|c|c|c|c|c|c|c|}
\hline Source of variation & $\begin{array}{l}\text { Rooting } \\
\text { percent }\end{array}$ & $\begin{array}{c}\text { Callus } \\
\text { percent }\end{array}$ & $\begin{array}{l}\text { Root } \\
\text { shoot } \\
\text { ratio }\end{array}$ & $\begin{array}{l}\text { Total } \\
\text { root } \\
\text { length }\end{array}$ & $\begin{array}{l}\text { Mean } \\
\text { root } \\
\text { length }\end{array}$ & $\begin{array}{c}\text { Root } \\
\text { number } \\
\text { per cutting }\end{array}$ & $\begin{array}{l}\text { Root } \\
\text { dry } \\
\text { mass }\end{array}$ & $\begin{array}{c}\text { Shoot } \\
\text { dry } \\
\text { mass }\end{array}$ \\
\hline Substrate & $\mathrm{NS}^{\mathrm{Z}}$ & $* * * *$ & $* * * *$ & $* *$ & $* * * *$ & $* *$ & $* * * *$ & $* * * *$ \\
\hline Wound & NS & NS & NS & $* *$ & $*$ & NS & $*$ & NS \\
\hline Substrate $\times$ wound & NS & NS & NS & NS & NS & NS & $*$ & NS \\
\hline K-IBA concentration & NS & NS & NS & $* *$ & $* * *$ & NS & $*$ & NS \\
\hline Substrate $\times$ K-IBA conc. & NS & NS & NS & NS & $*$ & NS & NS & NS \\
\hline Wound $\times$ K-IBA conc. & NS & NS & NS & NS & NS & NS & NS & NS \\
\hline Substrate $\times$ wound $\times$ K-IBA & NS & NS & NS & NS & NS & $*$ & NS & $*$ \\
\hline
\end{tabular}

${ }^{\mathrm{z}}$ Significant at $P \leq 0.05,0.01,0.001,0.0001=*, * *, * * *, * * * *$, respectively; NS $=$ non-significant at $P \leq 0.05$.

$\mathrm{K}$-IBA $=$ potassium salt of indole-3-butyric acid.
Rooting percentage was not significantly affected $(P \leq 0.05)$ by rooting substrates used, wounding treatments, or K-IBA concentrations. The lack of significance in the wounding and K-IBA treatments contradict the results of some experiments (De Silva et al., 2005; St. Hilaire, 2003; Zhou, 2005), whereas Copes and Randall (1993) found similar results using much lower IBA treatments. Rooting substrates, although non-significant at $P \leq 0.05$, were a significant treatment at $P \leq 0.1$ for rooting percentages (data not shown). Rooting percentages ranged from $\approx 53 \%$ in perlite to $\approx 36 \%$ in peatmoss. Cuttings in the mixture of the two substrates rooted at $\approx 43 \%$. Callus percentage was significantly affected $(P \leq$ 0.0001 ) by rooting substrates used (Table 3 ), thus suggesting that with more time, the rooting substrates might have significantly affected rooting percentage to a greater degree, because callus development has been shown to be a precursor to adventitious rooting of Taxodium stem cuttings (Jackson, 1986). Perlite, the substrate with the lowest water-holding capacity tested (Table 1), yielded the greatest percentage of callused cuttings at $85 \%$, whereas peatmoss, the substrate with the greatest water-holding capacity tested, yielded the fewest at $53 \%$ (Fig. 1A). Results for the mix of substrates were intermediate $(62 \%)$. Perhaps
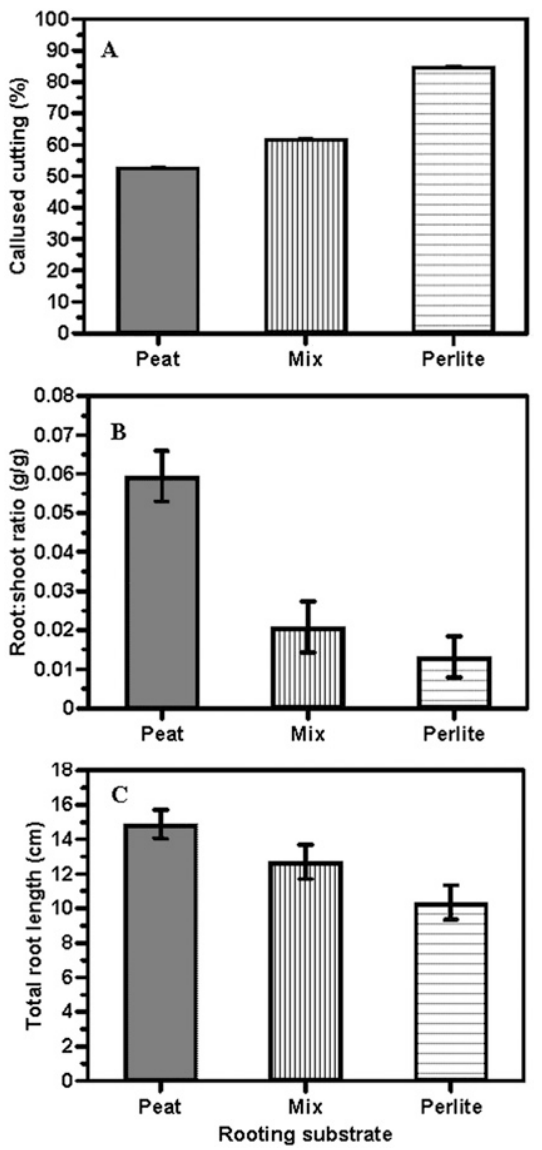

Fig. 1. Mean ( \pm SES) percentage of callused cuttings (A), root:shoot ratio of cuttings (B), total root length of cuttings $(\mathbf{C})$ for each of the three rooting substrates tested $(100 \%$ peatmoss, $100 \%$ perlite, or a 1:1 mix of peatmoss and perlite), $\mathrm{n}=24$. 
the greater macropore space of the lower waterholding capacity substrate permits greater oxygen penetration to the sites of callus and adventitious root development, which is known to be an active metabolic process (Wilson and Van Staden, 1990). No other treatment tested significantly affected the percentage of callused cuttings (Table 3 ).

The root:shoot ratio was also significantly affected $(P \leq 0.0001)$ only by the rooting substrate used (Table 3; Fig. 1B). Results for root:shoot ratio were opposite of those observed for callus percentage. The root:shoot ratio increased as water-holding capacity of the substrate increased. When adventitious rooting occurred, a greater water-holding capacity favored subsequent root growth, but a more porous substrate appeared to favor callus development. Peatmoss yielded cuttings with a root: shoot ratio of 0.059 , whereas cuttings planted in perlite had a ratio of only 0.013 . The $1: 1$ peatmoss:perlite mix yielded an intermediate ratio of 0.021 (Fig. 1B). No other treatment significantly affected root:shoot ratio (Table 3 ).

Main effects of rooting substrate, wounding treatment, and K-IBA concentration were significant $(P \leq 0.01)$ for total root length (Table 3 ). Rooting substrates significantly affected the total root length per cutting (Fig. 1C) and the results were similar to those found for root:shoot ratio (Fig. 1B). Peatmoss yielded cuttings with the greatest total root length $(14.9 \mathrm{~cm})$, whereas cuttings rooted in the peatmoss:perlite mix and perlite alone grew root systems of $12.7 \mathrm{~cm}$ and $10.3 \mathrm{~cm}$, respectively (Table 3; Fig. 1C). The more moist substrates apparently favored root development compared with the drier substrates once the root initiation phase gave way to the root elongation phase. The concentration of K-IBA applied significantly affected total root length (Table 3; Fig. 2A). The greatest concentration tested $\left(15,000 \mathrm{mg} \cdot \mathrm{L}^{-1}\right)$ yielded cuttings with total root lengths of $16 \mathrm{~cm}$, whereas root systems treated with the control were $10.8 \mathrm{~cm}$ per cutting. The two middle concentrations, 5,000 and $10,000 \mathrm{mg} \cdot \mathrm{L}^{-1} \mathrm{~K}$ IBA, produced cuttings with root systems of $11 \mathrm{~cm}$ and $12.8 \mathrm{~cm}$, respectively. These results closely follow those of Copes and Randall (1993) and Kolasinski (2006) and indicate that the basal necrosis that occurred when cuttings were treated with the two highest levels of K-IBA did not affect total root length. The wounding treatments also showed significant differences in total root length (Table 3; Fig. 3A). The non-wounded treatment yielded cuttings of $14.5 \mathrm{~cm}$ in total length, whereas the wounded cuttings only grew root systems of $10.8 \mathrm{~cm}$. Findings of the current research pertaining to the wounding of cuttings partially contradict those of Zhou (2005) in which wounding baldcypress cuttings not only significantly increased the rooting percentage, but also improved root system quality. Findings of the current research also differ with those reported in Kolasinski (2006) in which no significant $(P \leq 0.05)$ difference was found among incision wounded and non-wounded dawn redwood cuttings.
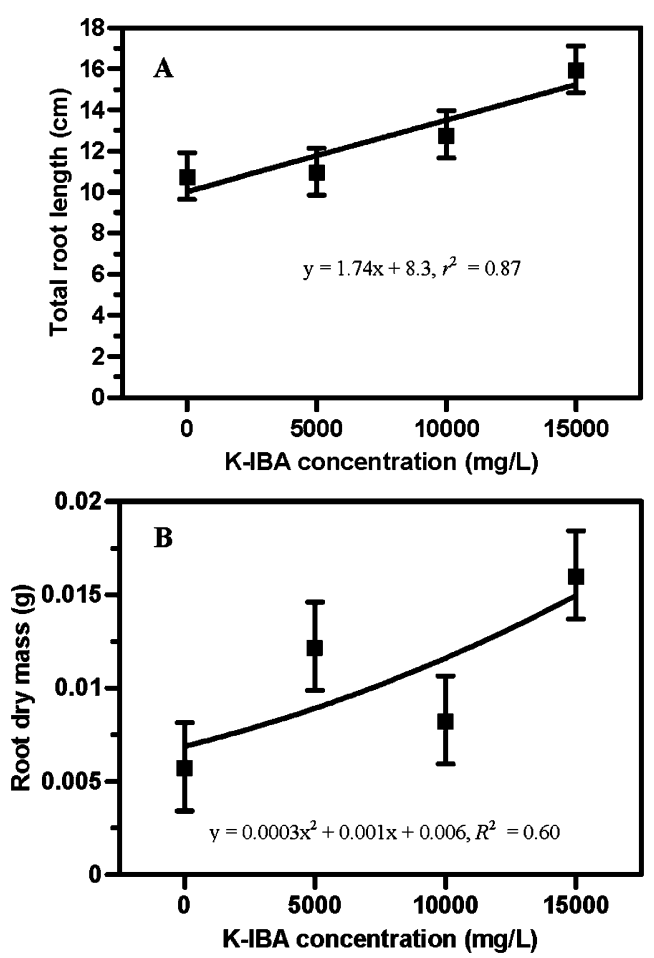

Fig. 2. Mean ( \pm SES) total root length (A) and root dry mass $(\mathbf{B})$ of cuttings in four K-IBA concentrations tested $\left(0,5,000,10,000\right.$ or $\left.15,000 \mathrm{mg} \cdot \mathrm{L}^{-1} \mathrm{~K}-\mathrm{IBA}\right), \mathrm{n}=18 . \mathrm{K}$-IBA $=$ potassium salt of indole-3-butyric acid.

Mean root length in the current study was significantly affected $(P \leq 0.05)$ by an interaction among rooting substrate and K-IBA concentration (Table 3; Fig. 4). Average root length was $11.9 \mathrm{~cm}$ for cuttings grown in peatmoss that had been treated with 15,000 $\mathrm{mg} \cdot \mathrm{L}^{-1} \mathrm{~K}-\mathrm{IBA}$. Cuttings grown in perlite produced shorter average root lengths ranging from $3.8 \mathrm{~cm}$ to $4.5 \mathrm{~cm}$ for the 0 and 10,000 $\mathrm{mg} \cdot \mathrm{L}^{-1} \mathrm{~K}-\mathrm{IBA}$ treatments, respectively. The peatmoss:perlite mix had intermediate average root lengths ranging from $5.1 \mathrm{~cm}$ to $8.9 \mathrm{~cm}$ for the 5,000 and $15,000 \mathrm{mg} \cdot \mathrm{L}^{-1} \mathrm{~K}$-IBA treatments, respectively. Cuttings rooted in peat also responded more positively to lower $\left(5,000 \mathrm{mg} \cdot \mathrm{L}^{-1}\right) \mathrm{K}-\mathrm{IBA}$ concentrations than cuttings rooted in the mixed or perlite substrates (Fig. 4). The greater root quality measurements, in this case average root length, were again found in cuttings that were grown in the substrate with the highest water-holding capacity and treated with the highest K-IBA concentration. When callus percentage data are used as a ceiling for rooting potential and the response of callus percentage is compared with the response of the root quality measurements (root:shoot ratio, total root length, average root length), there seems to be a tradeoff between achieving maximum possible rooting potential (root initiation) in a more aerated substrate and achieving optimal root quality (more related to root elongation) in a substrate with a greater water-holding capacity. This hypothesized tradeoff conflicts results found by Copes and Randall (1993) in which rooting percentage increased with increasingly moist substrates $(29 \%, 40 \%$, and $50 \%$ water content by weight, respectively). A significant $(P \leq 0.05)$ main effect of wounding
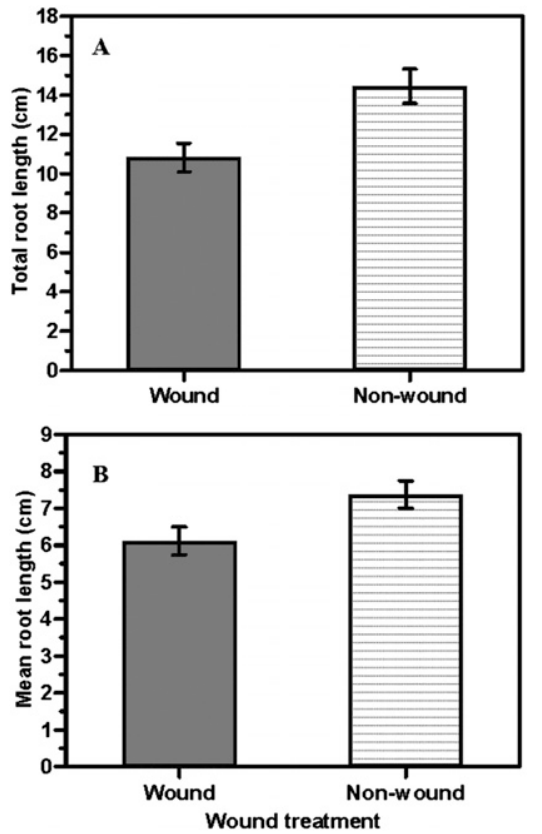

Fig. 3. Mean ( \pm SES) total root length (A) and mean ( \pm SES) root length $(\mathbf{B})$ of cuttings when tested with one of two wounding treatments (wound, non-wound), $\mathrm{n}=36$.

was also found for mean root length (Table 3). The average length of a given root was $7.4 \mathrm{~cm}$ for non-wounded cuttings versus $6.1 \mathrm{~cm}$ for the wounded treatments (Fig. 3B), differing with Kolasinski (2006) and again partially contradicting Zhou (2005). This result could be attributable in part to the fact that cuttings in Zhou (2005) were taken later in the season and 
those more mature cuttings might be less prone to the deleterious effects of wounding or have more suberized tissues in which wounding may be beneficial. Root length measurements alone, although necessary for root quality, cannot provide an adequate assessment of root system quality. The photograph in Figure 5A shows a cutting with high root quality for all measurements taken (total root length, mean root length, root number per cutting and root dry mass), whereas the cutting in Figure 5B had a high mean root length but low totals in all of the rest of the root quality measurements. The cutting in Figure 5B would be more likely to experience mortality (Goldfarb et al., 1998) and less vigorous initial growth (Foster et al., 1985; Struve et al., 1984).

Root number per cutting was significantly affected $(P \leq 0.05)$ by a three-way interaction (Table 3 ). The greatest values of mean root number per cutting were just above four and were found in cuttings that were not wounded, treated with either 0 or $5000 \mathrm{mg} \cdot \mathrm{L}^{-1} \mathrm{~K}-\mathrm{IBA}$, and rooted in perlite (Fig. 6A) or the mixed substrate (Fig. 6B). The fewest roots per cutting were found in cuttings planted in peatmoss across K-IBA concentrations and wounding treatments (Fig. 6C). Linear regression models (Fig. 6C) indicated that wounded and non-wounded cuttings in the peatmoss treatment produced only slightly different root numbers across all K-IBA concentrations. Some significant differences $(P \leq 0.05)$ in mean root number, however, were displayed between wounded and non-wounded cuttings in both the perlite (Fig. 6A) and peat:perlite mix (Fig. 6B) treatments. The wounded and non-wounded cuttings in the perlite treatment showed similar trends in relation to K-IBA concentrations; however, the non-wounded treatment produced significantly $(P \leq 0.05)$ greater numbers of roots in the 5,000 and $15,000 \mathrm{mg} \cdot \mathrm{L}^{-1} \mathrm{~K}-\mathrm{IBA}$ concentrations. The mixed substrate produced cuttings with root numbers that trended in opposite directions. Non-wounded cuttings in the mix substrate produced approximately four roots per cutting at the $0 \mathrm{mg} \cdot \mathrm{L}^{-1} \mathrm{~K}$-IBA concentration followed by a marked decrease at the intermediate $\mathrm{K}$-IBA concentrations to an increase at the $15,000 \mathrm{mg} \cdot \mathrm{L}^{-1} \mathrm{~K}-\mathrm{IBA}$ concentration (Fig. 6B). This differs from the results reported in Pezeshki and DeLaune (1994) in which treatment with IBA did not significantly affect root number. The wounded cuttings in the mixed substrate (Fig. 6B) produced significantly $(P \leq 0.05)$ fewer roots per cutting at the 0 and $15,000 \mathrm{mg} \cdot \mathrm{L}^{-1} \mathrm{~K}$-IBA concentrations than did the non-wounded treatment. Root numbers then increased in the wounded treatment at the intermediate K-IBA concentrations, which again contradicts part of Zhou's (2005) results.

Root dry mass was significantly affected $(P \leq 0.05)$ by an interaction between rooting substrate and wounding treatment (Table 3; Fig. 7) as well as a main effect of K-IBA concentration (Fig. 2B). The interaction appeared to be because of the root dry mass of the cuttings in the peatmoss, non-wounded treatment, which had an average mass of $0.026 \mathrm{~g}$, two and a half times greater than any other treatment.

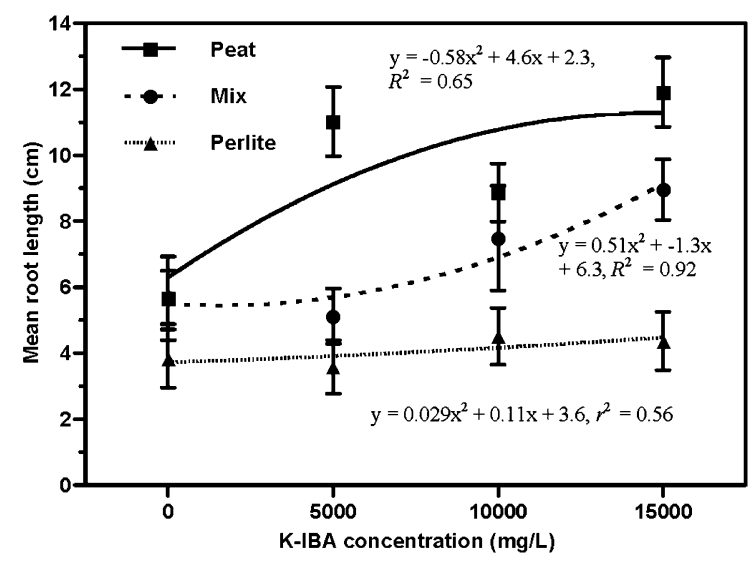

Fig. 4. Mean ( \pm SES) root length of cuttings in each of three rooting substrates $(100 \%$ peatmoss, $100 \%$ perlite, or a 1:1 mix of peatmoss and perlite) treated with one of four K-IBA concentrations $(0,5,000$, 10,000 , or $\left.15,000 \mathrm{mg} \cdot \mathrm{L}^{-1}\right), \mathrm{n}=6 . \mathrm{K}-\mathrm{IBA}=$ potassium salt of indole-3-butyric acid.
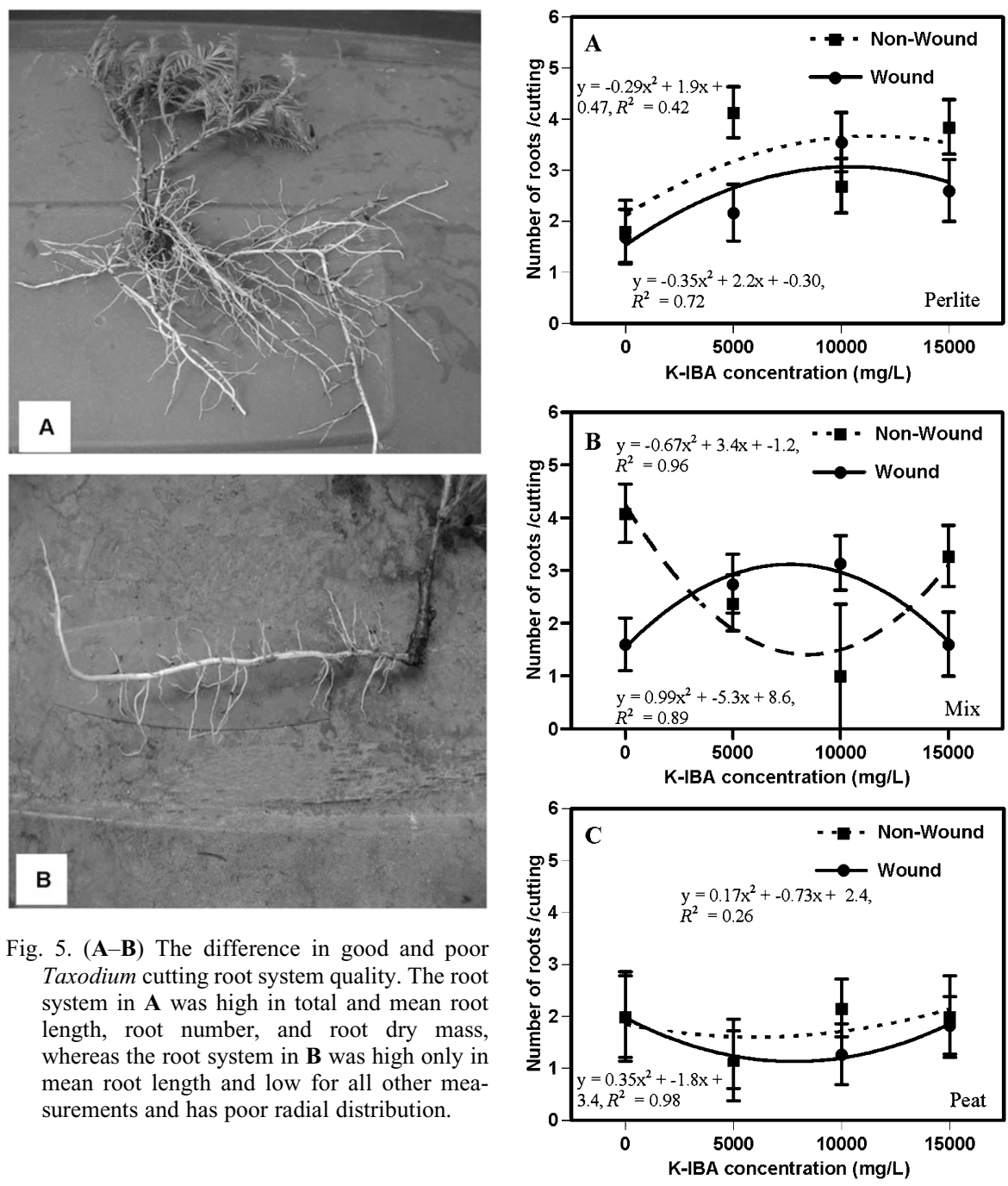

All other treatments were not significantly different (Fig. 7). This result supports the case for higher water-holding substrates yielding cuttings with higher quality root systems. The pattern of root dry mass in the K-IBA treatments was similar to those seen throughout the rest of the experiment (Fig. 2B). The 15,000 $\mathrm{mg} \cdot \mathrm{L}^{-1} \mathrm{~K}-\mathrm{IBA}$ concentration yielded cuttings
Fig. 6. Mean ( \pm SES) number of roots per cutting when treated with one of four K-IBA concentrations $\left(0,5,000,10,000\right.$, or $\left.15,000 \mathrm{mg} \cdot \mathrm{L}^{-1}\right)$, one of two wounding treatments (wound, nonwound) in $100 \%$ perlite (A), a $1: 1 \mathrm{mix}$ of peatmoss and perlite (B), or $100 \%$ peatmoss (C), $\mathrm{n}=3$. K-IBA = potassium salt of indole-3butyric acid. 
with $0.016 \mathrm{~g}$ of root dry mass and cuttings in the control $\left(0 \mathrm{mg} \cdot \mathrm{L}^{-1}\right)$ produced $0.006 \mathrm{~g}$ of root dry mass. This contrasts Pezeshki and DeLaune (1994) who found no effect of K-IBA applications on root quality measurements.

A significant $(P \leq 0.05)$ three-way interaction among rooting substrate, wounding

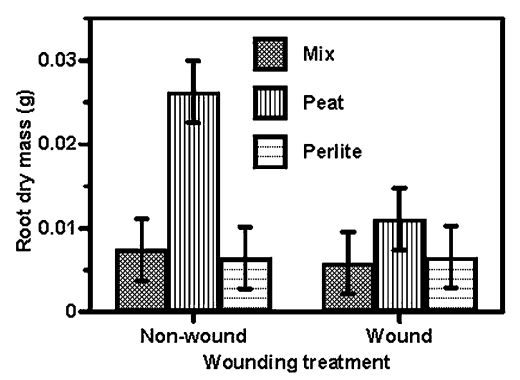

Fig. 7. Mean ( \pm SES) root dry mass of cuttings placed in one of three rooting substrates $(100 \%$ peatmoss, $100 \%$ perlite, or a 1:1 mix of peatmoss and perlite) with or without basal wounding, $\mathrm{n}=12$. treatment, and K-IBA concentration was observed in shoot dry mass (Table 3; Fig. 8A-C). The greatest shoot dry mass was $0.48 \mathrm{~g}$ found in cuttings inserted in perlite, $10,000 \mathrm{mg} \cdot \mathrm{L}^{-1}$ K-IBA, and not wounded (Fig. 8A). The lowest shoot dry mass was found for wounded cuttings grown in the peatmoss (Fig. 8C) substrate treated with the $15,000 \mathrm{mg} \cdot \mathrm{L}^{-1} \mathrm{~K}-\mathrm{IBA}$ concentration. This treatment produced mean shoot weights of $0.22 \mathrm{~g}$. Regression models show an inverse relationship among trends of wounded and non-wounded treatment responses in all three rooting substrates and across all K-IBA concentrations (Fig. 8A-C). Non-wounded cuttings in the peatmoss treatment (Fig. 8C) showed trend lines for shoot dry mass that were relatively flat with a small decrease for the intermediate K-IBA concentrations. The wounded treatment was almost inversed with the only significant difference occurring at the $15,000 \mathrm{mg} \cdot \mathrm{L}^{-1} \mathrm{~K}-\mathrm{IBA}$ concentration. The wounding treatments showed no significant difference to non-wounded cuttings in the mix substrate across all K-IBA
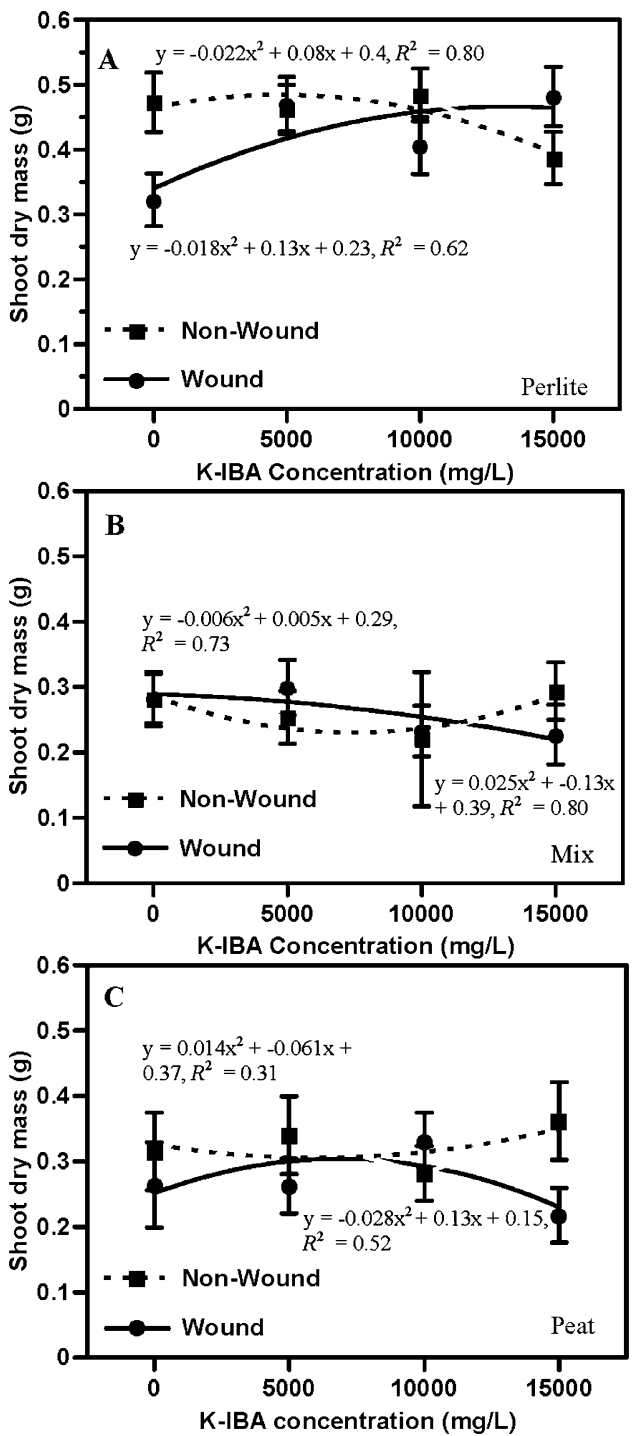

Fig. 8. Mean ( \pm SES) shoot dry mass of cuttings when treated with one of four K-IBA concentrations $(0$, $5,000,10,000$, or $\left.15,000 \mathrm{mg} \cdot \mathrm{L}^{-1}\right)$ with or without basal wounding in $100 \%$ perlite $(\mathbf{A})$, a $1: 1 \mathrm{mix}$ of peatmoss and perlite $(\mathbf{B})$, or $100 \%$ peatmoss $(\mathbf{C}), \mathrm{n}=3$. K-IBA $=$ potassium salt of indole-3-butyric acid.

concentrations but did trend in opposite directions at the $10,000 \mathrm{mg} \cdot \mathrm{L}^{-1}$ and 15,000 $\mathrm{mg} \cdot \mathrm{L}^{-1}$ concentrations (Fig. $8 \mathrm{~B}$ ). The perlite treatment showed significant differences $(P \leq$ $0.05)$ at the 0 and $15,000 \mathrm{mg} \cdot \mathrm{L}^{-1} \mathrm{~K}-\mathrm{IBA}$ concentrations. The non-wounded treatment had greater shoot dry mass at the $0 \mathrm{mg} \cdot \mathrm{L}^{-1} \mathrm{~K}-\mathrm{IBA}$ concentration and the wounded treatment had greater shoot dry mass at $15,000 \mathrm{mg} \cdot \mathrm{L}^{-1}$ K-IBA (Fig. 8A). This result in some ways conflicts with results found in Pezeshki and DeLaune (1994) in which shoot dry mass was significantly $(P \leq 0.05)$ affected by IBA treatment. This conflict could be explained by the fact that unlike the current research, Pezeshki and DeLaune (1994) did not include a wounding treatment or vary their rooting substrates. Shoot dry mass was greatest in the perlite treatment perhaps as a result of the greater incidence of callus tissue formation in that treatment.

The results of the current research suggest a tradeoff between greater rooting percentages in a substrate with greater aeration versus greater root quality in a substrate with higher waterholding capacity. Future research should focus on substrates with intermediate water-holding capacities in an attempt to optimize the effects of the suggested tradeoff. The K-IBA concentration did not affect rooting percentage as previously anticipated but did affect cutting quality. Contrary to some previous reports (Zhou, 2005), wounding the basal end of baldcypress cuttings proved to be detrimental to both rooted cutting percentage and root quality.

\section{Literature Cited}

Arnold, M.A. 2008. Landscape plants for Texas and environs. 3rd Ed. Stipes Publ., Champaign, IL.

Copes, D.L. and W.K. Randall. 1993. Rooting baldcypress stem cuttings. Tree Planters Notes 44:125-127.

De Silva, H., B.A. McKenzie, and M. Bloomberg. 2005. Indolebutyric acid and wounding induced rooting in callused, non-rooted Leyland cypress (X Cupressocyparis leylandii) stem cuttings. N. Z. J. Crop Hort. Sci. 33:407-412.

Dirr, M.A. 2009. Manual of woody landscape plants. 6th Ed. Stipes Publ., Champaign, IL.

Erstad, J.L.F. and H.R. Gislerod. 1994. Water uptake of cuttings and stem pieces as affected by different anaerobic conditions in the rooting medium. Sci. Hort. 58:151-160.

Foster, G.S., R.K. Campbell, and W.T. Adams. 1985. Clonal selection prospects in western hemlock combining rooting traits with juvenile height. Can. J. For. Res. 15:488-493.

Goldfarb, B., S.E. Surles, M. Thetford, and F.A. Blazich. 1998. Effects of root morphology on nursery and first-year field growth of rooted cuttings of Loblolly Pine. Southern J. Appl. For. 22:231-234

Grange, R.I. and K. Loach. 1983. The water economy of unrooted leafy cuttings. J. Hort. Sci. 58:9-17.

Hartmann, H.T., D.E. Kester, F.T. Davies, Jr., and R.L. Geneve. 2011. Hartmann and Kester's plant propagation: Principles and practices. 8th Ed. Prentice Hall, Upper Saddle River, NJ.

Jackson, M.B. 1986. New root formation in plants and cuttings. Martinus Nijhoff Publ., Dordrecht, The Netherlands.

King, A.R. 2010. Vegetative propagation and topophytic responses of selected baldcypress clones. 
MS thesis, Dept. Hort. Sciences, Texas A\&M Univ., College Station, TX.

Kolasinski, M. 2006. The effect of incision wounding of cuttings and of a rhizogenesis promoter on the rooting of Dawn Redwood (Metasequoia glyptostroboides Hu et Cheng). Elec. J. of Polish Agr. Univ. 9:1.

Lu, X., Z. Mao, Y. Chen, and L. Huang. 2004. Propagation technology of Taxodium 'zhongshansha'. J. Jiangsu For. Sci. \& Tech. 31:38-40 [abstract].

Mackenzie, K.A.D., B.H. Howard, and R.S. HarrisonMurray. 1986. The anatomical relationship between cambial regeneration and root initiation in wounded winter cuttings of the apple rootstock M.26. Ann. Bot. (Lond.) 58:649-661.

Mazăre, G., A. Dumitraş, D. Zaharia, L. Holonec, V. Ceuca, and A. Timofte. 2007. The obtaining of Picea cultivars by cuttings. Bul. Univ. Agr. Sci. and Vet. Med. Cluj-Napoca Horticulture 64:277-281.

Pezeshki, S.R. and R.D. DeLaune. 1994. Rooting of baldcypress cuttings. New For. 8:381-386.

Ragonezi, C., K. Klimaszewska, M.R. Castro, M Lima, P. de Oliveira, and M.A. Zavattieri. 2010. Adventitious rooting of conifers: Influence of physical and chemical factors. Trees (Berl.) 24:975-992.

Rein, W.H., R.D. Wright, and J.R. Seiler. 1991. Propagation medium moisture level influences adventitious rooting of woody stem cuttings. J. Amer. Soc. Hort. Sci. 116:632-636.

St. Hilaire, R. 2003. Propagation of Taxodium mucronatum from softwood cuttings. Desert Plants 19:29-30.
Struve, D.K., J.T. Talbert, and S.E. McKeand. 1984. Growth of rooted cuttings and seedlings in a 40 -year-old plantation of eastern white pine. Can. J. For. Res. 14:462-464.

Thomsen, A. 1978. Propagation of conifers by cuttings and grafting. IPPS Comb. Proc. 28: 215-219.

Wilson, P.J. and J. Van Staden. 1990. Rhizocaline, rooting co-factors, and the concept of promoters and inhibitors of adventitious rooting-A review. Ann. Bot. (Lond.) 66: 479-490.

Zhou, L. 2005. Salt tolerance, propagation and provenance evalution of Taxodium as a landscape and coastal wetland tree. MS thesis, Dept. of Horticulture, Stephen F. Austin State Univ., Nacogdoches, TX. 